\title{
Tamarisk Control, Water Salvage, and Wildlife Habitat Restoration Along Rivers in the Western United States
}

In the latter part of the 19th century, species of the nonnative shrub tamarisk (also called saltcedar; for example, Tamarix ramosissima, T. chinensis) were introduced to the United States for use as ornamental plants and for erosion control. By 1877, some naturalized populations had become established, and by the 1960s, tamarisk was present along most rivers in the semiarid and arid parts of the West and was quite abundant along downstream reaches of the major southwestern rivers such as the Colorado, Rio Grande, Gila, and Pecos. The principal period of tamarisk invasion coincided with changing physical conditions along western rivers associated with the construction and operation of dams. In many cases, these altered physical conditions appear to have been more favorable for tamarisk than native riparian competitors like cottonwoods and willows (Populus and Salix; Glenn and Nagler, 2005).

The great abundance of tamarisk along western rivers has led resource managers to seek to control it for various reasons, including a desire to (1) increase the flow of water in streams that might otherwise be lost to evapotranspiration (ET) (evapotranspiration is the combination of water lost as vapor from a soil or open water surface [evaporation] and water lost from the surface of the plant, usually from the stomata [transpiration]); (2) restore native riparian vegetation (here, "riparian" refers to the banks and flood plains of rivers, or shorelines of reservoirs or lakes); and (3) improve wildlife habitat.

\section{Water Salvage}

The concept of clearing riparian vegetation to increase streamflow and downstream water supply has been investigated by the U.S. Geological Survey (USGS), other Federal and State agencies, and academics since the 1950s. Simplistic estimates of potential increases in streamflow following tamarisk removal can be obtained by multiplying an evapotranspiration (ET) rate for tamarisk by the number of acres of a flood plain occupied by tamarisk. The estimates obtained from this product can be

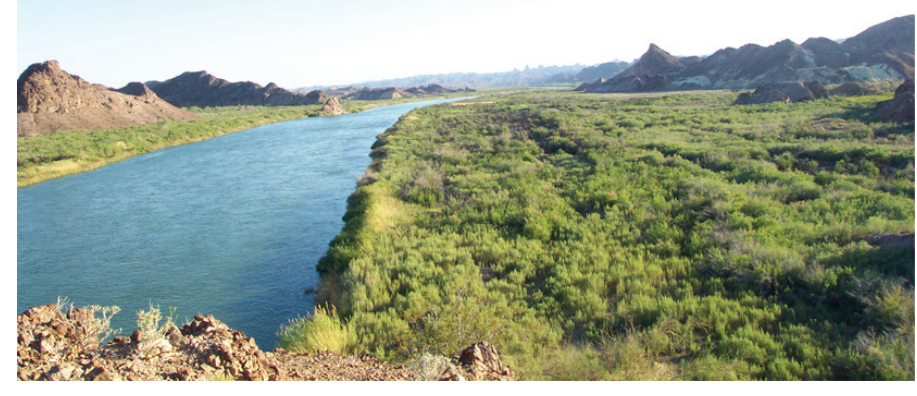

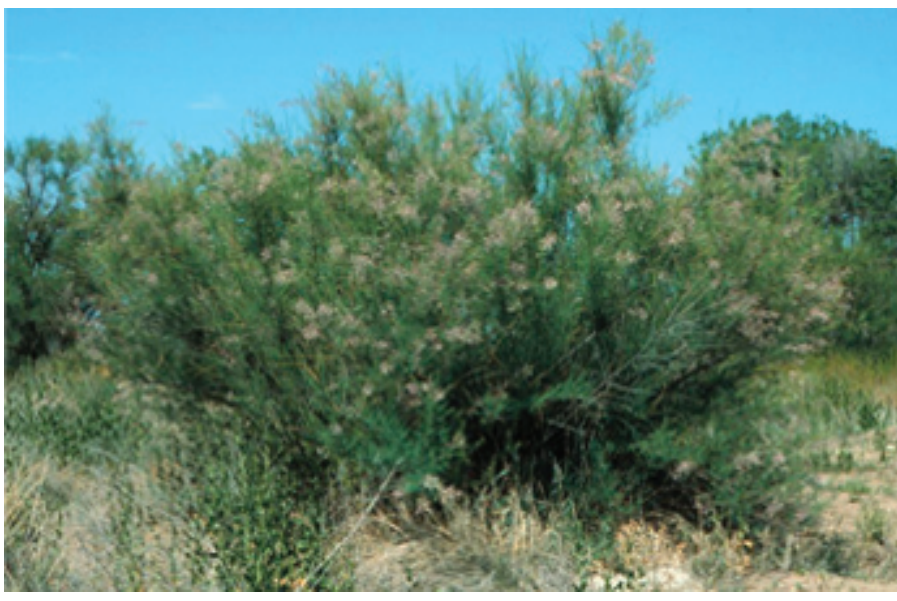

misleading because the ET values used are often overestimates (6-9 feet/year) based on studies of individual plants in wellwatered tanks. In field conditions, recent studies indicate that ET in tamarisk-dominated riparian vegetation is 2.5-4 feet/year (Dahm and others, 2002). In the 1970s and 1980s, the USGS conducted controlled studies of water budgets pre- and posttamarisk clearing along the Pecos and Gila Rivers. These studies suggest that measurable water salvage following tamarisk clearing is only 0-1.5 acre-feet/year due to ET of replacement vegetation, increased evaporation, loss to ground water, or other difficult-to-quantify "sinks" (Culler and others, 1982; Weeks and others, 1987; Shafroth and others, 2005).

\section{Riparian Restoration}

Often, restoration of native vegetation is a primary or secondary objective when clearing nonnative tamarisk. Approaches to restoring riparian vegetation following tamarisk removal may be active (for example, planting potted native plants, irrigating, and so forth), passive (for example, removing a stressor, or restoring natural processes), or hybrids (for example, spreading native seed in conjunction with a controlled reservoir release). Problematic tamarisk invasions usually occur in situations where the natural processes that favor native vegetation have been altered, tipping the balance in favor of tamarisk. These processes include natural patterns and quantities of streamflow and associated sediment and landform dynamics. Therefore, restoration efforts are most successful and sustainable when the underlying conditions favoring tamarisk invasion are addressed. Merely removing tamarisk generally will not lead to sustainable restoration of native riparian plant communities. Often, tamarisk or other alien weeds will simply recolonize the site over time (Stromberg, 2001; Shafroth and others, 2005). 


\section{Wildlife Habitat Implications}

Because native riparian forests in arid and semiarid parts of western North America are critical to the support of a variety of wildlife species, the purpose of riparian restoration is often to improve wildlife habitat. Although a number of studies have shown that many species (such as neotropical migratory birds) prefer native cottonwood and willow habitats to tamarisk, there are many taxa for which tamarisk provides suitable habitat (see Shafroth and others, 2005). The most prominent example is the federally listed southwestern willow flycatcher, which frequently nests in stands of tamarisk. Thus, the wildlife habitat implications associated with tamarisk control can be complex and controversial and can be closely linked to the restoration potential of a control site. In the absence of a carefully planned and executed restoration effort, the vegetation that is anticipated to replace tamarisk following removal may be an inferior substitute for many wildlife taxa. Further, flood-plain habitat conditions other than the vegetation alone may strongly influence wildlife populations, such as the frequency and magnitude of flooding and the complexity of different vegetation types and water sources throughout the flood plain. Simply removing tamarisk generally will not improve wildlife habitat. This must be accompanied by science-based restoration and monitoring plans to evaluate effectiveness.

\section{Control Techniques}

Various methods have been used to attempt to control existing stands of tamarisk along western rivers, including chemical, mechanical, and biological controls. Chemical control can be used for site-specific removal (for example, application to cut stumps) or for larger areas (areal spraying). Mechanical control generally involves cutting or bulldozing the above-ground material, raking up the root crowns, and burning the slash. Because chemical and mechanical approaches tend not to result in 100 percent mortality, followup control efforts are usually required. If the control site is still suitable for establishment of new tamarisk seedlings, then followup efforts may be required indefinitely. Biological control agents (herbivorous insects from tamarisk's native range in Asia) have recently been released at a number of field sites. The U.S. Department of Agriculture and partners are monitoring the results of these efforts, which are still at an early stage. Biological control is potentially more sustainable than other methods, but it is controversial because it involves introducing another nonnative organism, with potentially unforeseeable consequences. Long-term, sustainable control generally requires addressing the underlying causes of tamarisk invasion.

\section{Conclusions}

Controlling tamarisk for water salvage, riparian vegetation restoration, and wildlife habitat improvement has great appeal to land and water managers and to the public. However, all of these post-tamarisk removal objectives can be difficult to achieve over the long term without the input of the best scien- tific information. Sound, interdisciplinary science conducted by experts within the USGS has contributed to the present state of knowledge and is continuing to contribute to new, innovative approaches. For example, USGS scientists are conducting research to investigate many of the remaining uncertainties surrounding the issue of tamarisk management. These include mapping and modeling the current and future distribution of tamarisk; understanding the environmental conditions and processes associated with tamarisk invasions; comparing insect and bird use of tamarisk and restored riparian vegetation; and developing novel restoration approaches, including streamflow management downstream from dams and active planting of dry riparian sites.

\section{Literature Cited}

Culler, R.C., Hanson, R.L., Myrick, R.M., Turner, R.M., and Kipple, F.P., 1982, Evapotranspiration before and after clearing phreatophytes, Gila River flood plain, Graham County, Arizona: U.S. Geological Survey Professional Paper 655-P, 67 p.

Dahm, C.N., Cleverly, J.R., Coonrod, J.E.A., Thibault, J.R., McDonnell, D.E., and Gilroy, D.J., 2002, Evapotranspiration at the land/water interface in a semi-arid drainage basin: Freshwater Biology, v. 47, p. 831-843.

Glenn, E.P., and Nagler, P.L., 2005, Comparative ecophysiology of Tamarix ramosissima and native trees in western U.S. riparian zones: Journal of Arid Environments, v. 61, p. 419-446.

Shafroth, P.B., Cleverly, J.R., Dudley, T.L., Stuart, J., Taylor, J.P., van Riper, C., and Weeks, E.P., 2005, Control of Tamarix in the western U.S. - Implications for water salvage, wildlife use, and riparian restoration: Environmental Management, v. 35, p. 231-246.

Stromberg, J.C., 2001, Restoration of riparian vegetation in the south-western United States: importance of flow regimes and fluvial dynamism: Journal of Arid Environments v. 49, p. 17-34.

Weeks, E.P., Weaver, H.L., Campbell, G.S., and Tanner, B.D., 1987, Water use by saltcedar and by replacement vegetation in the Pecos River floodplain between Acme and Artesia, New Mexico: U.S. Geological Survey Professional Paper 491-G, 33 p.

For more information, contact:

Patrick B. Shafroth

USGS Fort Collins Science Center

2150 Centre Ave., Buillding C

Fort Collins, CO 80526

Phone: (970) 226-9327

e-mail: Pat_Shafroth@usgs.gov 